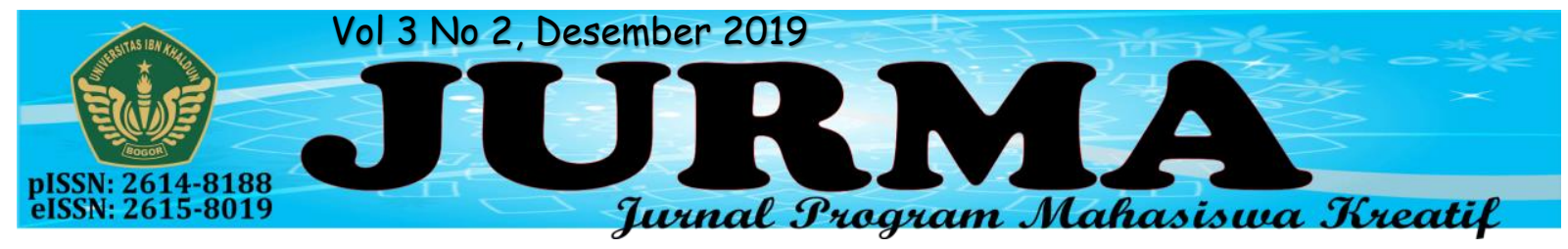

\title{
"PASARBAKUL" MEDIATOR PASAR KULINER UMAT MENYONGSONG PEREKONOMIAN UMAT MELALUI INOVASI APLIKASI ONLINE SHOP
}

\author{
Muhammad Ilham Aznun, Siti Meysari, Hakimee Yasing \\ m.ilham@gmail.com \\ Mahasiswa Fakultas Agama Islam Universitas Ibn Khaldun
}

\begin{abstract}
ABSTRAK
Kemajuan era digital saat ini semakin membuka peluang bangkitnya perekonomian di suatu negara. Saat ini belanja online sedang menjadi tren tersendiri dikalangan masyarakat dunia khususnya di Indonesia. Berbagai macam barang dapat kita peroleh melalui akad transaksi online yang benar-benar memberikan kemudahan bagi penjual maupun pembeli. Namun penyediaan kebutuhan kuliner belum menjadi arus penjualan utama via online shop. Dari ribuan jenis kuliner yang ada di Indonesia dengan keanekaragamannya, ternyata $64 \%$ terdiri dari bahan dasar yang sama yaitu beras, tepung, jagung, gula, daging, minyak goremg, susu, telur, sayuran dan lain-lain. Inilah yang menyebabkan bahan dasar kuliner sebagai peluang bisnis potensial yang akan kami kembangkan melalui marketplace berbsais aplikasi online shop dengan nama pasarbakul.com.
\end{abstract}

Kata Kunci: Inovasi Aplikasi, Perekonomian Umat, PASARBAKUL.

\section{PENDAHULUAN}

Kemajuan era digital saat ini semakin membuka peluang bangkitnya perekonomian di suatu negara terutama dalam membuat inovasi bisnis digital semakin berkembang dari hari ke hari. Salah satunya penggunaan smartphone yang semakin meningkat setiap tahunnya. Adanya fitur-fitur sosial media yang mudah diakses yang ditawarkan smartphone ini tentunya semakin mempermudah kita dalam berkomunikasi dan tetap terhubung dengan teman, sahabat, bahkan kerabat yang sulit kita jumpai dalam keseharian karena padatnya rutinitas. Dengan tersedianya fasilitas sosial media yang semakin memudahkan kita, tidak hanya dalam berkomunikasi tetapi juga dalam memenuhi kebutuhan hidup sehari-hari. Sehingga hanya dengan bermodalkan smartphone yang kita gunakan dalam keseharian ditunjang dengan fasilitas internet yang semakin luas, kita dapat mencoba suatu bentuk usaha yang dapat ditawarkan kepada konsumen melalui kemudahan transaksi via online.

Saat ini belanja online sedang menjadi tren tersendiri dikalangan masyarakat dunia khususnya di Indonesia. Berbagai macam barang dapat kita peroleh melalui akad transaksi online yang benarbenar memberikan kemudahan bagi penjual maupun pembeli. Transaksi online ini terjadi dengan adanya pasar online yang sering kita sebut dengan online shop. Dari kebutuhan primer sampai kebutuhan 
sekunder bisa kita dapatkan secara mudah melalui pembelian via online.

Namun penyediaan kebutuhan kuliner belum menjadi arus penjualan utama via online shop. Sehingga membuat kami tergerak untuk manjamah peluang yang sangat prospektif ini. Terbukti dimana salah satu jenis usaha yang tidak pernah surut adalah usaha di bidang kuliner. Dengan pertumbuhan 10,45\% pertahunnya menurut survei khusus ekonomi kreatif BPS dan BERKRAF 2016, yang menyebutkan sektor potensial di Indonesia didominasi oleh 3 sektor unggulan yaitu kuliner (41,69\%), fashion $(18,15 \%)$, kriya $(15,70 \%)$. Kemudian survei ini juga memperkuat analisis sektor unggulan perdagangan Indonesia yang masih di tempati oleh bahan baku makanan sebagai posisi pertama.

Dari ribuan jenis kuliner yang ada di Indonesia dengan keanekaragamannya, ternyata $64 \%$ terdiri dari bahan dasar yang sama yaitu beras, tepung, jagung, gula, daging, minyak goremg, susu, telur, sayuran dan lain-lain. Inilah yang menyebabkan bahan dasar kuliner sebagai peluang bisnis potensial yang akan kami kembangkan melalui marketplace berbsais aplikasi online shop dengan nama pasarbakul.com.

\section{Tujuan Usaha}

Tujuan kami mendirikan usaha ini, untuk memenuhi segala kebutuhan bahanbahan dasar kuliner dengan target market utama restoran kuliner dan ibu-ibu rumah tangga yang sulit berbelanja langsung ke pasar. Dengan aplikasi penjualan bahan dasar kuliner ini, kami berharap dapat mengefisienkan waktu pebisnis kuliner dan wirausahawan bahan dasar makanan dalam memasarkan produk mereka.

\section{Luaran}

1. Mampu memajukan perekonomian umat melalui lapak Online dengan ekonomi kreatif yang akan di isi oleh produsen dan distributor pribumi.

2. Mampu menciptakan suasana berbelanja dengan aman dan mudah.

\section{Kegunaan Program}

1. Bagi Mahasiswa

a. Menumbuhkan jiwa enterpreneurship dan jiwa kemadirian dalam hal finansial

b. Membuka peluang usaha baru

2. Bagi Produsen atau seller

a. Mempermudah penjual dalam memasarkan bahan baku kuliner

b. Meningkatkan keuntungan penjualan secara signifikan dengan menjaga efesiensi waktu.

c. Kami menawarkan kesempatan untuk produsen dan seller untuk memasarkan produknya secara global dengan berbasis online.

3. Bagi Konsumen

a. Mempermudah konsumen dalam mencari bahan baku kuliner

b. Menghemat waktu dalam berbelanja 


\section{GAMBARAN UMUM RENCANA USAHA}

Desain Dan Spesifikasi Produk

Pasar bakul merupakan inovasi mediator pasar kuliner umat yang akan memberikan informasi tentang segala kebutuhan bahan-bahan dasar kuliner kepada masyarakat terlebih utama pada ibu rumah tangga dan restoran-restoran.

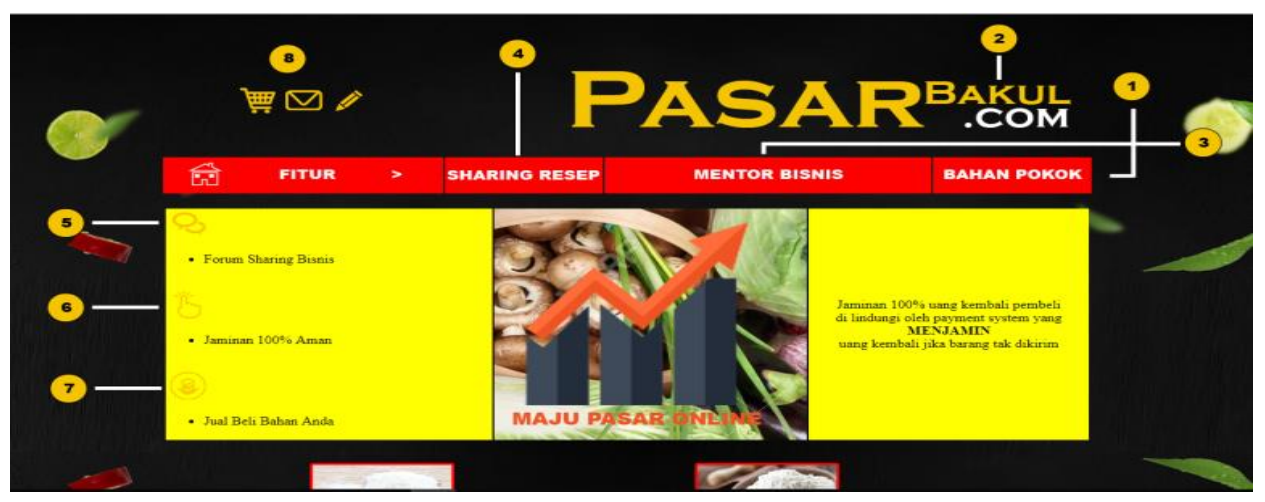

\section{Deskripsi Gambar}

1. Merupakan fitur penjualan bahan pokok makanan atau kuliner yang terkumpul dari berbagai produsen dan seller

2. Merupakan logo dari aplikasi kami dengan sasaran untuk memberikan transparasi bagi konsumen

3. Merupakan fitur bimbingan membangun bisnis kuliner yang akan dimentoring langsung oleh Ibu Yussi (Pebisnis kuliner di bidang catering dan kue kering)
4. Merupakan fitur yang menghubungkan para pecinta masak untuk saling berbagi resep

5. Merupakan fitur umum yang bisa dimanfaatkan oleh sesama pebisnis kuliner dalam membangun network mareketing muslim dan muslimah

6. Merupakan fitur yang menjamin uang kembai jika barang tidak dikirim

7. Merupakan fitur yang mengorganisir penjualan dari produsen dan seller

8. Merupakan fitur yang mengoperasionalkan cash on delivery dan jasa pengiriman langsung sampai.

\section{Analisis Prospek Usaha}

Prospek pengembangan usaha pasar bakul ini dapat dikaji dalam analisis SWOT (Strength, Weakness, Oppurtunity, Threat)

Tabel 1. Analisa SWOT

\begin{tabular}{|l|l|l|}
\hline Internal & $\begin{array}{l}\text { Strength } \\
\text { Metode : Konsep } \\
\text { produk unik }\end{array}$ & $\begin{array}{l}\text { Weakness } \\
\text { Market : }\end{array}$ \\
& Market : & $\begin{array}{l}\text { Belum adanya subsidi } \\
\text { ongkir }\end{array}$ \\
& $\begin{array}{l}\text { 2. Sebagian kecil } \\
\text { masyarakat belum } \\
\text { terbiasa dengan jual-beli } \\
\text { online }\end{array}$ \\
\hline
\end{tabular}




\begin{tabular}{|c|c|c|}
\hline External & $\begin{array}{l}\text { 2. Persaingan } \\
\text { cenderung sedikit }\end{array}$ & $\begin{array}{l}\text { 3. Masyarakat luas belum } \\
\text { mengenal aplikasi ini }\end{array}$ \\
\hline $\begin{array}{l}\text { Oppurtunity } \\
\text { Market : } \\
\text { 1. memberikan } \\
\text { kesempatan untuk } \\
\text { masyarakat } \\
\text { bertransaksi dengan } \\
\text { lebih simple } \\
\text { 2. menawarkan } \\
\text { kesempatan untuk } \\
\text { produsen dan seller } \\
\text { untuk memasarkan } \\
\text { produknya secara } \\
\text { global dengan } \\
\text { berbasis online }\end{array}$ & $\begin{array}{l}\text { Strategi } \\
\text { 1. iklan di } \\
\text { beberapa media } \\
\text { sosial seperti } \\
\text { facebook, } \\
\text { instagram, } \\
\text { whatsapp. } \\
\text { 2. Kerjasama } \\
\text { dengan ber } \\
\text { produsen bntuk } \\
\text { merk un } \\
\text { membangun } \\
\text { branding. }\end{array}$ & $\begin{array}{l}\text { Strategi } \\
\text { 1. Memberikan subsidi } \\
\text { ongkir bagi } \\
\text { pelanggan setia. } \\
\text { 2. } \\
\text { Mengikutsertakan } \\
\text { brand usaha dalam } \\
\text { beberapa event sosial } \\
\text { masyarakat. }\end{array}$ \\
\hline $\begin{array}{l}\text { Threat } \\
\text { Market : Munculnya } \\
\text { pesaing baru yang sama } \\
\text { produknya }\end{array}$ & $\begin{array}{l}\text { Strategi } \\
\text { 1. Terus membuat } \\
\text { inovasi baru } \\
\text { dalam } \\
\text { penambahan } \\
\text { fitur aplikasi. }\end{array}$ & $\begin{array}{l}\text { Strategi } \\
\text { 1. Ikut mengiklankan } \\
\text { brand usaha melalui } \\
\text { media cetak dan } \\
\text { online. }\end{array}$ \\
\hline
\end{tabular}

\section{Analisis Pasar}

\section{Geografis}

a. Lokasi uaha produksi berada di Bogor

b. Bogor merupakan kota yang memiliki banyak usaha di bidang kulinernya dan terdapat banyak hotel-hotel sehingga dapat mendukung usaha ini kedepannya.

c. Ketersediaan bahan baku yang murah dan akses yang mudah untuk pengiriman. Bogor juga memiliki sistem manajemen yang prospektif untuk berkembangnya usaha baru dan adanya daya tarik investor yang kuat.

\section{Demografis}

a. Segmen pasar yang dibidik adalah ibu rumah tangga, Pembantu rumah tangga, dan koki restauran atau hotel. Mealui aplikasi ibu rumah tangga, pembantu rumah tangga, dan koki restauran atau hotel dapat dengan mudah untuk memesan kebutuhan-kebutuhan dapur seperti sayuran, rempah-rempah dan bumbu dapur lainnya.

\section{Analisis Pesaing}

Dalam usaha ini terdapat pesaing, yaitu sebagai berikut :

1. Badan usaha yang menjual produk serupa dengan harga yang lebih rendah

2. Badan usaha yang menjual produk yang lebih kreatif dan inovatif 


\section{Rencana dan Strategi Pemasaran}

1.Rencana Pemasaran

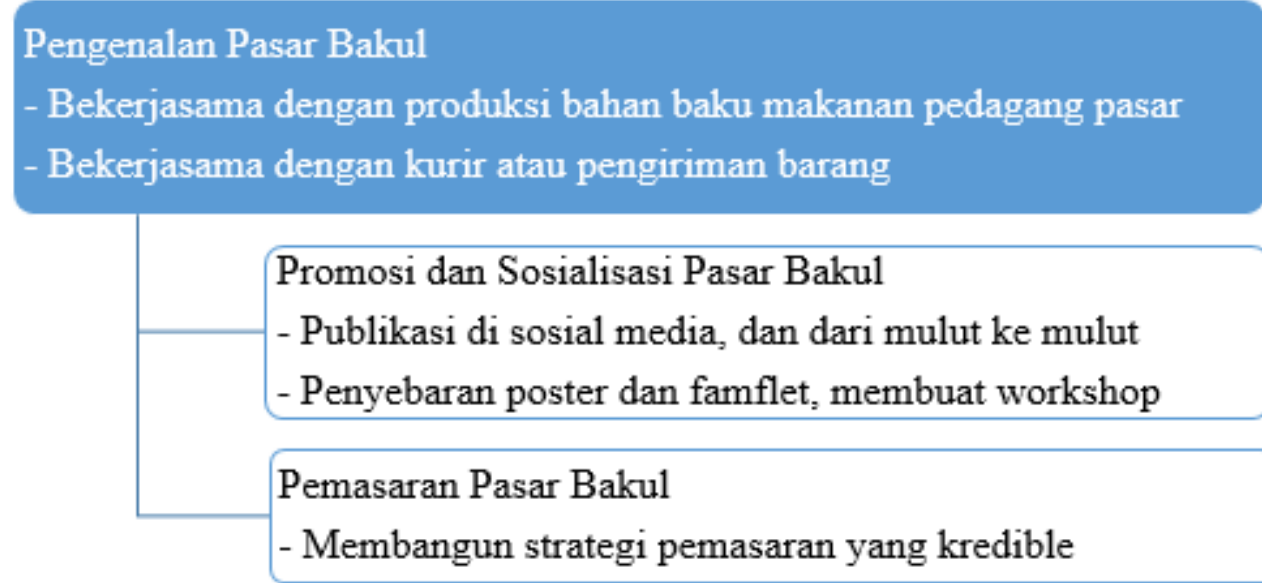

2.Strategi Pemasaran (Marketting Strategy)

- Membangun kerjasama dengan produsen yang sudah punya nama di masyarakat.

- Menggunakan fitur Augmented Reality.

- Adanya fitur klaim barang berguna untuk meningkatkan kepuasan pelanggan.

- Adanya fitur bayar di tempat yang berfungsi untuk menghindari ketidakpuasan pelanggan terhadap barang apabila barang tidak sesuai.

- Promotion Strategy.

- Pencantuman merk merk ternama. Bertujuan untuk menarik perhatian dari pelanggan. Merk tersebut akan di pasang di dalaman depan dari website dan aplikasi.

- Price Strategy

\section{Keberlanjutan Usaha}

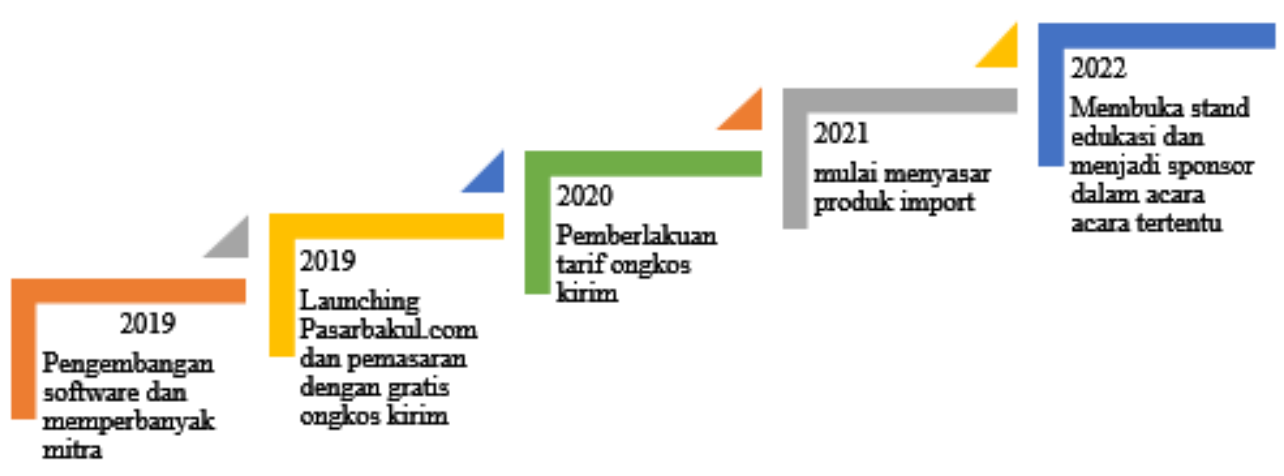

1. Pada tahun 2019 PasarBakul.com akan berfokus pada pengembangan Software, perbaikan server, dan pencarian mitra kerja

2. Pada tahun 2019 juga PasarBakul.com akan launching dan menjalankankan proses bebas ongkos kirim,pembebasan biaya kirim ini dianggap paling tepat untuk promosi terhadap segala segment yang biasanya terbebani oleh biaya pengiriman barang.

3. Pada tahun 2020 diharapkan PasarBakul.com sudah mendapatkan banyak pelanggan sehingga biaya pengiriman dapat diberlakukan 
4. Pada tahun 2021 diharapkan

menjadi sponsor agar banyak pasarbakul.com mulai menyasar pasar masyarakat yang lebih mengenal international

PasarBakul.com

5. Pada tahun 2022 kami berharap bisa ikut serta dalam event event tertentu dan

\section{Analisis Kelayakan Usaha}

1.Perhitungan Jumlah Produk yang Dihasilkan Tiap Kali Produksi

Tabel 2. Perhitungan Proyeksi Produksi

\begin{tabular}{|c|c|c|}
\hline Hari & Penjualan & Proyeksi \\
\hline 1. & 100 & $\frac{100+102+105}{3}=102,33$ \\
\hline 2. & 102 & $\frac{102+105+103}{3}=103,33$ \\
\hline 3. & 105 & $\frac{105+103+105}{3}=104,33$ \\
\hline 4. & 103 & $\frac{103+105+106}{3}=104,67$ \\
\hline 5. & 105 & $\frac{105+106+106}{3}=105,67$ \\
\hline 6. & 106 & $\frac{106+106+108}{3}=106,67$ \\
\hline 7. & 106 & $\frac{106+108+110}{3}=108$ \\
\hline 9. & 108 & \\
\hline
\end{tabular}

Keterangan :

Perhitungan menggunakan moving average atau rata-rata bergerak sehingga hari ke tujuh proyeksinya 61,67, karena kami menghitung dengan proyeksi mingguan.

Tabel 3. Perhitungan Proyeksi Penjualan

\begin{tabular}{|c|c|c|}
\hline Hari & Produksi $\times$ Penjualan & Penjualan \\
\hline 1. & $105 \times 100.000$ & Rp. 10.500 .000 \\
\hline 2. & $103 \times 100.000$ & Rp. 10.300 .000 \\
\hline 3. & $105 \times 100.000$ & Rp. 10.500 .000 \\
\hline 4. & $106 \times 100.000$ & Rp. 10.600 .000 \\
\hline 5. & $106 \times 100.000$ & Rp. 10.600 .000 \\
\hline 6. & $108 \times 100.000$ & Rp. 10.800 .000 \\
\hline 7. & $110 \times 100.000$ & Rp. 11.000 .000 \\
\hline \multicolumn{2}{|r}{} & Rp.74.300.000 \\
\hline
\end{tabular}


Keterangan :

Kami menghitung proyeksi penjualan ini per satu minggu yang totalnya sebesar Rp.41.500.000. Jika dihitung perbulan maka Rp.41.500.000 x $4=166.000 .000$

Tabel 4. Perhitungan Proyeksi Laba Rugi

\begin{tabular}{|c|c|c|}
\hline Hari & Produksi x Penjualan & Penjualan \\
\hline 1. & $105 \times 23.500$ & Rp.2.467.500 \\
\hline 2. & $103 \times 23.500$ & Rp.2.420.500 \\
\hline 3. & $105 \times 23.500$ & Rp.2.467.500 \\
\hline 4. & $106 \times 23.500$ & Rp.2.491.000 \\
\hline 5. & $106 \times 23.500$ & Rp.2.491.000 \\
\hline 6. & $108 \times 23.500$ & Rp.2.538.000 \\
\hline 7. & $110 \times 23.500$ & Rp.2.585.000 \\
\hline \multicolumn{2}{|c|}{ Total } & Rp. 17.460 .500 \\
\hline
\end{tabular}

Keterangan :

Kami menghitung proyeksi penjualan ini per satu minggu yang totalnya sebesar Rp.17.460.500. Jika dihitung perbulan maka Rp.17.460.500 x 4 = Rp.69.842.000

\section{Perhitungan Penganggaran Modal}

\section{a.Permodalan}

1)Pembelian bahan baku sebesar Rp. 4.800 .000 x $30=144.000 .000$

2)Perlengkapan Rp. 10.750 .000

Total Modal $=154.750 .000$

b.Biaya Operasional

Tabel 5. Fixed Cost (Biaya Tetap)

\begin{tabular}{|l|l|l|}
\hline No. & Keterangan & Jumlah Biaya \\
\hline 1. & Biaya Pemasaran & 1.600 .000 \\
\hline 2. & Biaya Perlengkapan & 800.000 \\
\hline 3. & Biaya Tenaga Kerja & 450.000 \\
\hline \multicolumn{2}{|l}{ Total Fixed Cost } & Rp. 2.850 .000 \\
\hline
\end{tabular}

Tabel 6. Variabel Cost (Biaya Variabel)

\begin{tabular}{|l|l|l|l|l|}
\hline No. & Nama Barang & Harga Satuan & Quantity & Jumlah Harga \\
\hline 1. & Aplikasi & 3.000 .000 & 1 Buah & 3.000 .000 \\
\hline 2. & Hosting & 500.000 & 1 Buah & 500.000 \\
\hline 3. & Domain & 500.000 & 1 Buah & 500.000 \\
\hline 4. & Desain Website & 800.000 & 1 Buah & 800.000 \\
\hline \multicolumn{4}{|l}{ Total Variabel Cost } & Rp.4.800.000 \\
\hline
\end{tabular}


3.Analisis Titik Impas (Break Event Point)

Tabel 7. Break Event Point

\begin{tabular}{|c|c|c|}
\hline \multicolumn{3}{|c|}{ Perhitungan Harga Jual Per Satuan } \\
\hline Harga Jual & $\begin{array}{l}\frac{2.850 .000+4.800 .000}{100 \text { Buah }} \\
=76.500 / \mathrm{Buah}\end{array}$ & $\begin{array}{l}\text { Harga Jual } 100 \quad \mathrm{x} \\
100.000=10.000 .000\end{array}$ \\
\hline Harga Produksi & $\begin{array}{l}100 \times 76.500= \\
7.650 .000\end{array}$ & \\
\hline Laba Usaha & $\begin{array}{l}100.000-76.500= \\
23.500\end{array}$ & $\begin{array}{l}10.000 .000-7.650 .000 \\
=2.350 .000\end{array}$ \\
\hline Harga Jual Per Buah & $\begin{array}{l}76.500+23.500= \\
100.000\end{array}$ & \\
\hline
\end{tabular}

\section{KETERANGAN:}

$\begin{array}{ll}\mathrm{Y} & \text { : Laba } \\ \mathrm{c} & \text { : HargaJual } \\ \mathrm{X} & \text { : Jumlahproduk yang dijual } \\ \mathrm{b} & \text { : Biayavariabel per satuan } \\ \mathrm{a} & \text { : Biayatetap total } \\ \mathrm{cx} & \text { : Hasilpenjualan } \\ \mathrm{bx} & \text { : Biayavariabel total }\end{array}$

Jadi Break Event Pointnya adalah :

- $\mathrm{X}$ BEP dalam unit $=\frac{a}{(c-b)}=\frac{2.850 .000}{(100.000-76.500)}=\frac{2.850 .000}{23.500}=121,27 \mathrm{Buah}$

- $\mathrm{X}$ BEP dalam rupiah $=\frac{a}{1-b / c)}=\frac{2.850 .000}{1-76.500 / 5.150 .000)}=\frac{2.850 .000}{1-0.014}=$ $\frac{2.850 .000}{0,986}=R p .2 .890 .466,53$

- Kontribusi Margin $=3,6 \%$

4.Laporan Arus Kas

Tabel 8. Arus Kas

\begin{tabular}{|lrl|}
\hline Penjualan & $100 \times 100.000$ & $=\mathrm{Rp} \cdot 10.000 .000$ \\
Biaya-biaya : & 1.600 .000 & \\
Biaya pemasaran & 800.000 & \\
Biaya perlengkapan & 450.000 & \\
Biaya tenaga kerja & 4.800 .000 & $=(\mathrm{Rp} .7 .650 .000)$ \\
Biaya bahan baku & & $=\mathrm{Rp} .2 .350 .000$ \\
Total biaya & & \\
Laba bersih & & \\
\hline
\end{tabular}


Tabel 9. Neraca

\begin{tabular}{|lcl|}
\hline $\begin{array}{l}\text { AKTIVA } \\
\text { Aktiva Lancar }\end{array}$ & & $\begin{array}{l}\text { PASSIVA } \\
\text { Passiva Lancar }\end{array}$ \\
$\begin{array}{l}\text { Kas } \\
\text { Piutang }\end{array}$ & 4.800 .000 & Hutangdagang \\
$\begin{array}{l}\text { Perlengkapan } \\
\text { Total Aktiva Lancar }\end{array}$ & $\begin{array}{l}10.750 .000+ \\
\\
\text { Aktiva Tetap }\end{array}$ & \\
$\begin{array}{l}\text { Peralatan } \\
\text { Total Aktiva }\end{array}$ & - & \\
\hline
\end{tabular}

6.Proyeksi Laporan Laba Rugi

Tabel 10. Laporan Laba Rugi

\begin{tabular}{|c|c|c|}
\hline Penjualan & $100 \times 100.000 \times 30$ hari & $=$ Rp. 300.000 .000 \\
\hline HPP & $100 \times 76.500 \times 30$ hari & $=\underline{\text { Rp. } 229.500 .000-}$ \\
\hline Laba kotor/margin & & $=$ Rp. 70.500 .000 \\
\hline Biaya-biaya: & & \\
\hline Biaya pemasaran & 1.600 .000 & \\
\hline Biaya perlengkapan & 800.000 & \\
\hline Biaya tenaga kerja & $\underline{450.000}$ & \\
\hline Total biaya tetap & \multicolumn{2}{|c|}{2.850 .000} \\
\hline Biaya bahan baku & \multicolumn{2}{|c|}{$4.800 .000 \times 4=\underline{19.200 .000}$} \\
\hline Total biaya variabel & \multicolumn{2}{|c|}{19.200 .000} \\
\hline Total biaya & & $\mathrm{Rp}(22.050 .000)$ \\
\hline Laba Bersih & & Rp. 48.450 .000 \\
\hline
\end{tabular}

7.Laporan Proyeksi Laporan Perubahan Modal

Tabel 11. Laporan Perubahan Modal

Modal awal

Laba bersih

Modal akhir

$$
\begin{aligned}
& =\text { Rp. } 154.750 .000 \\
& =\text { Rp. } 48.450 .000+ \\
& =\text { Rp.106.300.000 }
\end{aligned}
$$




\section{GAMBARAN UMUM RENCANA USAHA}

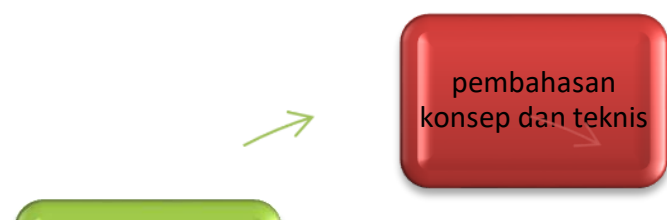

Promosi

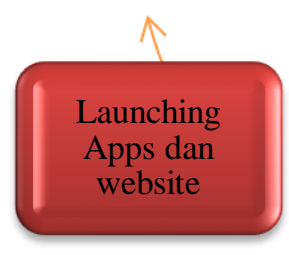

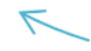

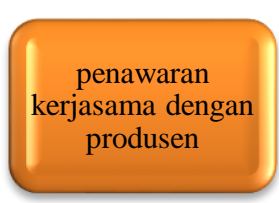

\section{Pembahassan konsep dan teknis}

Mempelajari survei dan kelayakan proyek pengembangan sistem informasi, yang kemudian akan kita tuangkan dalam proposal.

\section{Pembuatan website dan aplikasi}

Diawali dengan melakukan pembelian template yang sudah terintegrasi, kemudian membuat konten provider melalui wordpress CMS. Hinnga melakukan testing produk sebelum launch.

\section{Demo aplikasi dan website}

Melakukan simulasi atau Demo website dan aplikasi apakah sudah sesuai dan dapat running sesuai desain atau tidak.

\section{Penawaran kerjasama dengan investor}

Dalam kerjasama ini akan disepakati dengan penandatanganan kontrak pembuatan

website dan

Aplikasi

Demo aplikasi

dan website penawaran

kerjasama dengan investor

mengenai pembagian keuntungan dan pendanaan lainnya.

\section{Penawaran kerjasama dengan produsen}

Target produsen yang dituju dalam hal ini merupakan perusahaan dengan branding yang sudah ada. Hal ini bertujuan untuk memperoleh produsen yang terverifikasi.

\section{Launching Apps dan website}

Sebelum melakukan launching diperlukan re-design dan penambahan fitur untuk memperoleh website dan aplikasi yang optimal.

\section{Promosi}

Promosi ini bertujuan untuk mengenalkan website dan aplikasi yang pada akhirnya dapat meningkatkan penjualan produk. 
BIAYA DAN JADWAL KEGIATAN

Biaya Kegiatan

\begin{tabular}{|c|l|c|}
\hline No. & \multicolumn{1}{|c|}{ Jenis Pengeluaran } & Biaya (Rp) \\
\hline 1. & Peralatan Penunjang (Fixed Cost) & 2.850 .000 \\
\hline 2. & Bahan habis Pakai (Variabel Cost) & 4.800 .000 \\
\hline 3. & Working Capital & 10.750 .000 \\
\hline \multicolumn{2}{|c|}{ Total } & 18.400 .000 \\
\hline
\end{tabular}

Jadwal Kegiatan

\begin{tabular}{|c|c|c|}
\hline Kegiatan & Bulan & Idikator \\
\hline \multicolumn{3}{|l|}{ Persiapan } \\
\hline 1. Pembuatan proposal & & Proposal siap \\
\hline $\begin{array}{l}\text { 2. Pengajuan proposal pada } \\
\text { sponsor }\end{array}$ & & $\begin{array}{l}\text { Proposal sampai ke donatur, } \\
\text { dan partner }\end{array}$ \\
\hline 3. Perjanjian dengan tender & & $\begin{array}{l}\text { Kedua belah pihak sepakati } \\
\text { kerjasama }\end{array}$ \\
\hline 4. Persiapan bahan baku & & Bahan baku siap \\
\hline 5. Persiapan alat produksi & & Alat produksi siap \\
\hline \multicolumn{3}{|l|}{ Pelaksanaan } \\
\hline 1. Pembuatan desain & & $\begin{array}{l}\text { Melalui pembelian template } \\
\text { yang terintegrasi dan } \\
\text { membuat konten provider } \\
\text { dengan menggunakan } \\
\text { wordpress CMS }\end{array}$ \\
\hline 2. Demo aplikasi dan website & & $\begin{array}{l}\text { Re-design dan penambahan } \\
\text { fitur sebelum launch }\end{array}$ \\
\hline 3. Promosi dan publikasi & & $\begin{array}{l}\text { Promosi produk terutama } \\
\text { pada kalangan ibu-ibu dan } \\
\text { media sosial }\end{array}$ \\
\hline 4. Menjalankan program & & $\begin{array}{l}\text { Memperkenalkan } \\
\text { pasar bakul ke roduk } \\
\text { restorant }\end{array}$ \\
\hline 5. Evaluasi & & $\begin{array}{ll}\text { Indikator } & \text { keberhasilan } \\
\text { program } & \end{array}$ \\
\hline 6. Pelaporan & & Laporan selesai \\
\hline
\end{tabular}




\section{DAFTAR PUSTAKA}

http://m.detik.com/finance/berita-ekonomi-

bisnis/d-3366011/bekraf-dan-bps-

luncurkan-data-statistik-ekonomi-

kreatif-2016

Faisal Reza (2016). Strategi Promosi Penjualan Online lazada.co.id. Jurnal Kajian Komunikasi, Bandung.

HARIS FADHILA (2016). Pasar Kuliner,

Seni Dan Kerajinandi Kota
Magelang dengan penekanan arsitektur Kontemporer. Under Graduates thesis, Universitas Negeri Semarang

Kotler, P. \& Armstrong, G. (2008). Prinsip-Prinsip Pemasaran Jilid 1 Edisi Keduabelas Terjemahan. Jakarta: Erlangga. 